\title{
MANAJEMEN SARANA DAN PRASARANA
}

\section{Ike Malaya Sinta}

Madrasah Tsanawiyah Ar Rosyidiyah

Jl. Cikuda No.001 RT.01 RW.11 Pasirbiru Urban Village Cibiru Sub, Pasir Biru, Kec. Cibiru, Kota Bandung, Jawa Barat 40615

Email: Ikemalayasintha@gmail.com

\begin{abstract}
ABSTRAK
Penelitian ini dilatar belakagi oleh: faktor keterbatasan luas lahan sekolah yang tidak sesuai dengan standar sarana dan prasarana untuk membangun prasarana sekolah berupa bangunan gedung dan tempat bermain/olahraga. Perencanaan pengadaan sarana dan prasarana, pihak madrasah mengajukan proposal untuk menerima bantuan tetapi tidak semua proposal yang diajukan dari pihak madrasah mendapatkan hasil yang diinginkan sehingga proses pembelajaran kurang optimal karena sarana dan prasarana kurang memadai. Proses pengelolaan sarana dan prasarana masih belum berjalan dengan optimal dimulai dari penginventarisasian, pemakaian pemeliharaan, dan penghapusan sarana dan prasarana. Oleh Karen aitu, proses pengelolaan sarana dan prasarana ini masih dibutuhkannya perbaikan. Tujuan penelitian ini adalah untuk mengetahui dan mendeskripsikan perencanaan, pengadaan, pemakaian, penginventarisasian, penghapusan, faktor penghambat dan penunjang sarana dan prasarana di Madrasah Aliyah Swasta Ar-Rosyidiyah Bandung. Penelitian ini merupakan penelitian kualitatif dengan memakai metodede skriptif analitik. Pengumpulan data dilakukan dengan wawancara, observasi, danstudi dokumentasi. Teknik analisis data dilakukan melalui penafsiran deskriptif, uji keabsahan data, perpanjangan keikutsertaan, dan auditing. perencanaan sarana dan prasarana dilakukan dengan cara mengajukan bantuan kepada pihak pemerintah, pengadaan sarana dan prasarana dilaksanakan sesuai dengan perencanaan sarana dan prasarana, pemakaian dan pemeliharaan sarana dan prasarana sesuai dengan kebutuhan siswa, penginventarisasian yang sesuai dengan ketentuan data setiap tahunnya, penghapusan barang dilakukan dengan secara kondisional berdasarkan kondisi barang, faktor penghambat manajemen sarana dan prasarana adalah kurangnya dana, adapun faktor penunjangnya adalah fasilitas madrasah sudah memadai, berdasarkan hasil penelitian ini disarankan agar pihak madrasah lebih fokus lagi dalam penempatan fasilitas bagi siswa, agar pengguna fasilitas tersebut merasakan nyaman.
\end{abstract}

Kata Kunci: Manajemen, Sarana, dan Prasarana 


\section{ABSTRACT}

This research is motivated by: the factor of the limited area of school land that is not in accordance with the standards of facilities and infrastructure for building school infrastructure in the form of buildings and playgrounds / sports. Planning the procurement of facilities and infrastructure, the madrasas submit a proposal to receive assistance but not all proposals submitted from the madrasas get the desired results so that the learning process is not optimal because the facilities and infrastructure are inadequate. The process of managing facilities and infrastructure is still not running optimally starting from inventory, use of maintenance, and elimination of facilities and infrastructure. Therefore, the process of managing these facilities and infrastructure is still needed improvement. The purpose of this study was to find out the objective conditions of Facility and Infrastructure Management in MAS Ar-Rosyidiyah Bandung. Planning of madrasa facilities and infrastructure, procurement of madrasa facilities and infrastructure, use and maintenance of madrasah facilities and infrastructure, inventory of facilities and infrastructure elimination of madrasah facilities and infrastructure, inhibiting factors and Management of Facilities and Infrastructure Management, Management of Facilities and Infrastructure in MAS Ar-Rosyidiyah.This research is a qualitative research using descriptive analytic method. Data collection is done by interviews, observation, and documentation studies. Data analysis techniques were carried out through descriptive interpretation, data validity testing, extended participation, and auditing.planning of facilities and infrastructure carried out by proposing assistance to the government, procurement of facilities and infrastructure carried out in accordance with the facilities and infrastructure planning, the use and maintenance of facilities and infrastructure in accordance with the needs of students, inventory in accordance with the provisions of the data every year, removal of goods carried out conditionally based on the condition of the goods, ) inhibiting factors of facilities and infrastructure are always hampered by funds in terms of procurement planning, while the supporting factors are adequate madrasah facilities) based on the results of this study it is suggested that the madrasah focus more on the placement of facilities for students, so that users of these facilities feel comfortable .

\section{PENDAHULUAN}

Pendidikan memiliki peran penting terhadap kualitas pembangunan suatu negara. Kemajuan suatu negara dapat terlihat dari berkualitasnya pendidikan. Suatu negara yang mengalami ketertinggalan pendidikan akan mempunyai hambatan dalam proses pembangunannnya, baik-buruknya suatupendidikan, dapat menentukan baik-buruknya kualitas pembangunan suatu negara. (Moh. Munir, 2014; 135)

Proses pembelajaran merupakan inti dari proses pendidikan formal dengan guru sebagai pemeran utama. Guru yang kompeten dan profesional akan lebih mampu dalam menyampaikan materi pelajaran, sehingga hasil belajar siswa berada pada tingkat yang optimal. Guru merupakan faktor yang penting dalam meningkatkan kualitas pembelajaran. Namun bukan berarti keberadaan unsur-unsur lain tidak begitu penting bagi peningkatan mutu 
pendidikan di sekolah. Guru membutuhkan layanan yang profesional di bidang sarana dan prasarana dalam menerapkan kemampuannya secara maksimal.

Keberhasilan program pendidikan melalui proses pembelajaran sangat dipengaruhi oleh banyak faktor, salah satu diantaranya adalah tersedianya sarana dan prasarana pendidikan yang memadai disertai pemanfaatan dan pengelolaan secara optimal. Sarana dan prasarana pendidikan merupakan salah satu sumber daya yang penting dan utama dalam menunjang proses pembelajaran di sekolah, untuk itu perlu dilakukan peningkatan dalam pendayagunaan dan pengelolaannya, agar tujuan yang diharapkan dapat tercapai.

Fasilitas pendidikan merupakan salah satu faktor penentu keberhasilan pendidikan.Kelengkapan dan ketersediaan fasilitas pendidikan di sekolah sangat berpengaruh terhadap keefektifan dan kelancaran pembelajaran di dalam kelas.Secara sederhana, manajemen perlengkapan sekolah dapat didefinisikan sebagai proses kerjasama pendayagunaan semua perlengkapan pendidikan secara efektif dan efisien." Berdasarkan definisi sederhana tersebut maka pada hakikatnya manajemen sarana dan prasarana pendidikan di sekolah itu merupakan proses pendayagunaan semua sarana dan prasarana yang dimiliki sekolah.Semua fasilitas atau sarana dan prasarana sekolah haruslah dikelola dengan baik agar keberadaan sarana dan prasarana tersebut dapat menunjang proses pembelajaran dan digunakan sesuai kebutuhan, sehingga pembelajaran di kelas dapat berjalan lancar dan tujuan pendidikan dapat terwujud. Dalam kegiatan pembelajaran sarana dan prasarana sangat diperlukan dalam rangka menunjang kelancaran proses kegiatannya, sehingga pengelolaan sarana dan prasarana sangat diperlukan oleh setiap instansi terutama sekolah (Hajeng Darmastuti, 2014:10).

Sarana dan prasarana pendidikan merupakan salah satu sumber daya yang penting dalam menunjang proses pembelajaran di sekolah. Keberhasilan program pendidikan di sekolah sangat dipengaruhi oleh kondisi sarana dan prasarana pendidikan yang dimiliki sekolah dan oleh optimalisasi pengelolaan dan pemanfaatannya (Nurhattati Fuad, 2016:1).

Sarana dan prasarana merupakan faktor penting yang akan menentukan apakah sebuah proses pembelajaran bisa berjalan efektif atau justru sebaliknya. Untuk mewujudkan proses pembelajaran yang baik dibutuhkan alat dan media yang digunakan sebagai penunjang. Sebagai contoh, proses pendidikan tidak bisa berjalan dengan efektif jika ruang kelas yang digunakan sebagai tempat belajar tidak terawat atau bahkan sudah tidak layak pakai.Oleh karena itu, pengelolaan terhadap sarana dan prasarana dalam sebuah lembaga pendidikan harus dilakukan secara profesional dan proporsional.

Berdasarkan Peraturan Pemerintah Nasional Republik Indonesia pasal 1 Nomor 19 Tahun 2005 tentang standar sarana prasarana menyatakan bahwa: Standar sarana prasarana adalah standar nasional pendidikan yang berkaitan dengan kriteria minimal tentang ruang belajar, tempat berolahraga, tempat beribadah, perpustakaan, laboratorium, bengkel kerja, tempat bermain, tempat berkreasi dan berekreasi serta sumber belajar lain, yang diperlukan untuk menunjang proses pembelajaran, termasuk penggunaan teknologi informasi dan komunikasi. 
Manajemen sarana dan prasarana pendidikan juga dapat didefinisikan sebagai proses kerjasama pendayagunaan semua sarana dan prasarana pendidikan secara efektif dan efisien. Definisi ini menunjukkan bahwa sarana dan prasarana yang ada di insttitusi pendidikan tinggi perlu didayagunakan dan dikelola untuk kepentingan proses pembelajaran di insttitusi pendidikan tinggi. Pengelolaan itu dimaksudkan agar dalam menggunakan sarana dan prasarana di insttitusi pendidikan tinggi bisa berjalan dengan efektif dan efisien. Pengelolaan sarana dan prasarana merupakan kegiatan yang amat penting di insttitusi pendidikan tinggi, karena keberadaannya akan sangat mendukung suksesnya proses pembelajaran (M. Muchlis Solichin, 2011: 155).

Manajemen sarana prasarana adalah pengelolaan terhadap seluruh perangkat alat, bahan, dan fasilitas lainnya yang digunakan dalam sebuah proses kegiatan belajar mengajar sehingga proses kegiatan belajar bisa berjalan dengan efektif. Suharsimi Arikunnto (2002) menjelaskan bahwa sarana pendidikan memiliki beberapa klasifikasi yang bisa dibedakan sebagai berikut: "Bangunan sekolah (tanah dan gedung) yang meliputi: halaman sekolah, ruang kelas, ruang guru, kantor ruang praktek, ruang tamu, ruang kepala sekolah, ruang perpustakaan, laboratorium, mushola, dan kamar kecil. Perabot sekolah yang meliputi: meja guru, meja murid, kursi, lemari, rak buku, sapu, dan kotak sampah".

Menurut Ary.H. Gunawan (1996:14) dalam bukunya yang berjudul Administrasi Sekolah tentang Manajemen Sarana Prasarana bahwasannya Proses Belajar Mengajar (PBM) atau kegiatan Belajar Mengajar (PBM) akan semakin sukses apabila ditunjang dengan sarana dan prasarana pendidikan yang memadai, sehingga pemerintah yang selalu berupaya untuk secara terusmenerus melengkapi sarana dan prasarana pendidikan bagi seluruh jenjang dan tingkat pendidikan sehingga kekayaan fisik Negara yang berupa sarana dan prasarana pendidikan telah menjadi sangat besar.

Agar sarana dan prasarana pendidikan yang dibutuhkan sekolah berfungsi optimal dalam mendukung pembelajaran disekolah, maka diperlukan warga sekolah (kepala sekolah, guru, dan tenaga administrasi) yang memahami dan mampu mengelola sarana dan prasarana pendidikan secara profesional.Hal ini sejalan dengan kebijakan yang telah digariskan oleh Kemdikbud tentang standar kompetensi yang harus dimiliki oleh warga sekolah.Salah satu kompetensi yang harus dimiliki oleh warga sekolah adalah kompetensi manajerial sekolah yaitu kepala sekolah harus memiliki kemampuan mengelola sarana dan prasarana sekolah dalam rangka pendayagunaannya secara optimal (Nurhattati Fuad, 2016: 4).

Manajemen sarana dan prasarana pendidikan bertugas mengatur dan menjaga sarana dan prasarana pendidikan agar dapat memberikan kontribusi secara optimal dan berarti pada jalannya proses pendidikan. Kegiatan pengelolaan ini meliputi kegiatan perencanaan, pengadaan, pengawasan, penyimpanan inventarisasi dan penghapusan serta penataan ( $E$. Mulyasa, 2002: 49-50).

Manajemen sarana dan prasarana yang baik diterapkan dapat menciptakan sekolah yang bersih, rapi, indah sehingga menciptakan kondisi yang menyenangkan baik bagi guru maupun murid untuk berada di sekolah. Di samping itu juga diharapkan tersedianya alat-alat atau fasilitas belajar yang 
memadai secara kuantitatif, kualitas relevan dengan kebutuhan serta dapat dimanfaatkan secara optimal untuk kepentingan proses pendidikan dan pengajaran, baik oleh guru sebagai pengajar maupun murid-murid sebagai pelajar (E. Mulyasa, 2002:50).

Manajemen sarana dan prasarana pendidikan merupakan salah satu bagian kajian dalam administrasi sekolah (School administration), atau administrasi pendidikan (educational administration) dan sekaligus menjadi bidang garapan kepala sekolah selaku administrator sekolah. Secara sederhana, manajemen sarana dan prasarana pendidikan dapat didefinisikan sebagai proses kerja sama pendayagunaan semua perlengkapan pendidikan secara efektif dan efesien (Putri Isnaeni Kurniawati, 2013:101).

Administrasi Sarana dan Prasarana pendidikan merupakan seluruh proses kegiatan yang direncanakan dan diusahakan secara sengaja dan bersungguh-sungguh serta Pembinaan secara continue terhadap benda-benda pendidikan, agar senantiasa siap-pakai (ready for use) dalam PBM semakin efektif dan efesien guna membantu tercapainya tujuan pendidikan yang telah ditetapkan (Ary.H. Gunawan, 1996:114).

Sarana dan prasarana pendidikan juga sebagai salah satu unsure manajemen pendidikan yang memiliki peranan penting dalam proses belajar mengajar, sarana pendidikan merupakan hal yang tidak boleh diabaikan. Sarana dan prasarana pendidikan juga digunakan untuk mempermudah pemahaman siswa tetang materi yang disampaikan dengan menggunakan sarana dan prasarana pendidikan yang tepat dalam program kerja mengajar menjadi lebih efektif dan efesien. Dengan adanya sarana dan prasarana pendidikan kegiatan belajar mengajar akan menjadi lebih bermakna dan berkualitas dan menyenangkan (Rika Megasari, 2014:638).

Ditinjau dari jenisnya, fasilitas pendidikan dapat dibedakan menjadi fasilitas fisik dan fasilitas nonfisik.Fasilitas fisik atau fasilitas nonfisik yaitu segala sesuatu yang berwujud benda mati atau dibendakan yang mempunyai peran untuk memudahkan atau melancarkan sesuatu usaha, seperti kendaraan, mesin tulis, komputer, perabot, alat peraga, model, media, dan sebagainya. Fasilitas nonfisik yakni sesuatu yang bukan benda mati, atau kurang dapat disebut benda atau dibendakan, yang mempunyai peranan untuk memudahkan atau melancarkan sesuatu usaha seperti manusia, jasa, dan uang (Ary.H. Gunawan, 1996:115).

Manajemen sarana dan prasarana pendidikan di sekolah direncanakan oleh kepala sekolah, seorang manajer dapat membuat suatu perencanaan yang tepat dan dapat melaksanakan program-program sarana dan prasarana di sekolah.Pengadaan sarana dan prasarana pendidikan adalah suatu upaya yang dilakukan oleh kepala sekolah, dan memelihara sarana dan prasarana pendidikan dengan baik (Sri Marmo'ah, 2014:26).

Berdasarkan hasil studi pendahuluan yang dilaksanakan di MAS ArRosyidiyah pada hari senin 1 Januari 2018 pukul 12:42 WIB s.d selesai dengan narasumber lbu Dra. Ivo Rosna Novera selaku wakil kepala sekolah bidang kurikulum dan bapak Eman Sulaeman selaku bidang sarana prasarana, di dalam bidang Manajemen Sarana Prasarana di MAS Ar-Rosyidiyah seluruh komponen yang tersedia berjalan dengan optimal, baik itu dari segi inventaris, pengadaan, pemeliharaan, pengawasan sampai penghapusan. Tetapi dalam 
hal tersebut masih ditemukannya beberapa masalah yang terjadi, pertama menurut standar sarana dan prasarana, luas lahan sekolah harus dapat digunakan secara efektif untuk membangun prasarana sekolah berupa bangunan gedung dan tempat bermain/olahraga tetapi luas lahan MAS ArRosyidiyah tidak sesuai dengan sesuai ketentuan Standar Sarana dan Prasarana.Kedua dalam hal perencanaan pengadaan sarana dan prasarana, pihak madrasah mengajukan proposal untuk menerima bantuan dari pihak yayasan tetapi tidak semua proposal yang diajukan dari pihak madrasah mendapatkan hasil yang diinginkan sehingga proses pembelajaran kurang optimal karena sarana dan prasarana kurang memadai. Ketiga proses pengelolaan sarana dan prasarana masih belum berjalan dengan optimal dimulai dari penginventarisan, pemakaian pemeliharaan, sampai penghapusan sarana dan prasarana. Oleh karena itu, proses pengelolaan sarana dan prasarana ini masih dibutuhkannya perbaikan.

\section{METODE}

Secara garis besar metodologi penelitianakan menjelaskan lima tahapan kegiatan yang dilakukan yaitu: 1) menentukan pendekatan dan metode penelitian, 2) menentukan jenis data dan sumber data, 3) menentukan tempat dan waktu penelitian, 4) teknik pengumpulan data, 5) teknik analisis data, dan 6) uji keabsahan data. Teknik pengumpulan data dilakukan ialah dengan teknik wawancara, observasi, dan studi dokumentasi. Peneliti melakukan wawancara melalui percakapan tanyajawab untuk memperoleh informasi dari narasumber. Observasi dilakukan melalui pengamatan baik secara langsung maupun tidak langsung dengan menggunakan seluruh pancaindera. Studi dokumentasi dilakukan untuk mengumpulkan dokumen dan data-data pendukung terkait dengan penelitian. Teknik analisis data penelitian dimulai dari analisis data sebelum di lapangan, analisis data di lapangan yaitu reduksi data, penyajian data, verifikasi/kesimpulan, dan analisis data selama di lapangan. Sedangkan teknik keabsahan data terdiri dari perpanjangan pengamatan, meningkatkan ketekunan, triangulasi, analisis kasus negative, menggunakan bahan referensi dan mengadakan membercheck.Uji absah data dilakukan untuk membuktikan bahwa data yang diterima merupakan data yang sebenarnya terdapat pada tempat penelitian.

\section{HASIL PENELITIAN DAN PEMBAHASAN}

\section{Latar Alamiah Madrasah Aliyah Swasta Ar-Rosydiyah Bandung}

Madrasah Aliyah Swasta (MAS) Ar-Rosyidiyah Bandung berada dibawah naungan yayasan berdiripada Tahun 1983 yang dipimpin oleh Bapak Alm $\mathrm{H}$. Muhammad Qudsi selaku tokoh masyarakat dan tokoh pendidikan yang berada di Jl Cikuda Pasirbiru dan pendiri lainnya adalah Bapak Alm. Drs. H. Saefullah, Bapak Abdurrahman, Bapak H. Enuy, dan Bapak H. Otoy. Ketua Yayasan ArRosyidiyah itu sendiri adalah Bapak H Usuf sekarang di lanjut oleh Bapak Drs. H. Agus Rahmat, M.M.Pd. sampai sekarang.Yayasan Ar-Rosyidiyah adalah jenjang pendidikan Islamiyah yang pertamakali ada di Pasirbiru, yayasan ArRosyidiyah berdiri atas dukungan masyarakat sekitar karena faktor lingkungan yang pada saat itu belum ada sekolah bernuansa islamiyah. Yayasan ArRosyidiyahberdiri pada tahun 1983.Jenjang pendidikan yang pertamakali 
didirikan yaitu Madrasah Tsanawiyah dan Madrasah Diniyah.Madrasah Tsanawiyah berjalan sampai tahun 1992.Seiring berjalannya waktu yayasan ArRosyidiyah membangun kembali Madrasah Aliyah pada tahun 1992 dengan menerima siswa seadanya pada saat itu.Madrasah dibangun dengan tanah hak milik yayasan sendiri bukan merupakan tanah wakaf.Yayasan Ar-Rosyidiyah membangun kembali Raudthul Atfal (RA) pada Tahun 2000. Selanjutnya yayasan Ar-Rosyidiyah akan merencanakan mendirikan Madrasah Ibtidaiyah pada Tahun 2019. Dalam pelaksanaan pembangunan Madrasah di mulai dari Madrasah Aliyah Swata Ar-Rosyidiyah memulai jenjang pendidikan dari Madarasah Tsanawiyah (MTs), Madrasah Diniyah (MD), Madrasah Aliyah (MA), Raudatul Atfal (RA), dan Madrasah Ibtidaiyah (MI). Hal ini merupakan pembangun Madrasah yang terus menerus berdasarkan kebutuhan masyarakat sekitar. Jadi dalam proses pembangunan Madrasah tersebut tidak berurutan seharusnya didirikan dari jenjang pendidikan bawah terlebih dahulu seperti Raudathul Atfal (RA), Madrasah Diniyah, Madrasah Ibtigaiyah, Madrasah Tsanawiyah, dan Madrasah Aliyah.

Dalam perkembangan selanjutnya Yayasan Ar-Rosyidiyah mengalami perpindahan tempat ke Jl Cikuda, PasirBiru, Cibiru pada Tahun 1998 atas dari bantuan BAPPENAS (Badan Perencanaan Pembangunan Nasional) yang sebelumnya yayasan Ar-Rosyidiyah berada di lokasi Jl Cikuda, Pasirbiru tetapi berbeda RW saja. Yayasan Ar-Rosyidiyah memiliki dua kampus yakni kampus satu dan kampus dua, kampus satu berada di samping Jl Cikuda, Pasirbiru dan lokasi kampus dua berada di belakang kampus satu berada di belakang kampus satu yang hanya berbeda RW saja.

Yayasan Ar-Rosyidiyah kini dinamai Madrasah Aliyah Swasta ArRosyidiyah berada di Jl. Cikuda, Desa Pasirbiru, Kecamatan Cibiru, Kota Bandung. Sudah memiliki jenjang pendidikan Madrasah Aliyah, Madrasah Tsanawiyah, dan Madrasah Diniyah bertempatan di kampus satu, sedangkan yang berada di kampus dua sekaligus Madrasah yang pertamakali didirikan yaitu ditempati oleh Raudhatul Athfal (RA) dan DTA (Diniyah Takmiliyah Awaliya/PAUD). Madrasah Aliyah Swasta (MAS) Ar-Rosyidiyah Bandung sudah memiliki akreditasi (A).

Madrasah Aliyah Swasta Ar-Rosyidiyah Bandung berada di Jl. Cikuda Desa, Pasirbiru, Kecamatan.Cibiru Kota Bandung Jawa Barat.Keadaan sarana dan prasarana Madrasah Aliyah Swasta Ar-Rosyidiyah Bandung sudah sangat memadai. Madrasah Aliyah Swasta Ar-Rosyidiyah Bandung merupakan salah satu Madrasah Swasta yang berakreditasi A, dengan begitu jika dunia pendidikan memiliki akreditasi $A$ pasti sudah dipandang baik bagi pemerintah dan masyarakat. Madrasah Aliyah Swasta Ar-Rosyidiyah Bandung memiliki luas tanah wakaf 4200 ha. Terdiri dari dua bangunan sekolah seluas 1216 ha, lapangan olahraga 72 ha, halaman sekolah 1568 ha, dan lahan yang belum digunakan 1344ha.

Madrasah Aliyah Swasta Ar-Rosyidiyah Bandung memiliki dua bangunan sekolah terdiri dari dua lantai kondisi bangunan layak untuk dipakai. Bangunan madrasah memiliki 9 kelas, halaman sekolah seluas 1568 terlihat kecil sehingga sering dipakai lahan parkir sepeda motor bagi para guru dan murid, lapangan olahraga berada di belakang sekolah ada satu lapangan olaharaga dipakai untuk voley, basket dan tenis. 
Madrasah Aliyah Swasta Ar-Rosyidiyah Bandung dilihat dari keadaan sarana dan prasarananya sudah memadai.Kondisi bangunan Madrasah pun terlihat layak dipakai hanya saja ada beberapa kondisi sarana dan prasarana yang rusak. Madrasah Aliyah Swasta Ar-Rosyidiyah Bandung memiliki fasilitas penunjang yaitu: sembilan ruang kelas tiga kelas berkondisi rusak berat, satu Ruang Kepala Madrasah, satu Ruang Guru, satu Ruang Tata Usaha, satu Laboratorium Fisika, satu Laboratorium Fisika, satu Laboratorium Biologi, satu Laboratorium Komputer, satu Ruang Perpustakaan, satu Ruang UKS, tiga Toilet Guru, lima Toilet Siswa, satu Ruang Bimbingan Konseling (BK), satu Ruang Osis, satu Ruang Pramuka, satu Masjid/Mushola, satu Gedung/Ruang Olahraga, satu Pos Satpam berkondisi baik, tiga kantin berkondisi baik.

Dilihat dari kondisi sarana dan prasarananya, Madrasah Aliyah Swasta ArRosyidiyah Bandung sudah menunjang fasilitas yang sudah dibutuhkan oleh siswa.Dimulai dari segi bangunannya peralatan yang mendukung pembelajaran siswa sampai peralatan ekstrakurikulernya. Keadaan prasarana di Madrasah Aliyah Swasta Ar-Rosyidiyah Bandung sudah memadai seperti: kursi siswa, meja siswa, loker untuk siswa di ruangan kelas, kursi guru di ruang kelas, meja guru di ruang kelas, papan tulis, lemari di ruang kelas digunakan untuk guru, komputer/laptop di Laboratorium komputer, alat peraga untuk PAl, alat peraga fisika, alat peraga biologi, alat peraga kimia, bola sepak, bola voli, bola basket, meja pingpong (tenis meja), lapangan sepakbola/futsal, lapangan bulutangkis, lapangan basket, dan lapangan bola voli. Berikut ada rincian pendataan mengenai jumlah ruangan kelas yang ada di Madrasah Aliyah Swasta ArRosyidiyah Bandung.

\section{Perencanaan sarana dan prasarana madrasah}

Proses perencanaan yang dilakukan terhadap sarana dan prasarana harus sesuai dengan kebutuhan dan kondisi madrasah. Perencanaan pengadaan sarana dan prasarana berdasarkan dari aspek analisis kebutuhan sarana dan prasarana dan proyeksi kebutuhan sarana dan prasarana.

Madrasah Swasta Ar-Rosyidiyah Bandung merencanakan penambahan pembangunan sarana/gedung bertempat di belakang gedung sekolah tetapi terhambat oleh dana. Sumber dana yang diterima oleh Madrasah Aliyah Swasta Ar-Rosyidiyah Bandung selama ini adalah dari pihak pemerintah setempat yakni pemerintaha pusat dan pemerintah daerah selalu mengirim bantuan terhadap madrasah adapun jenis bantuan tersebut yaitu berupa bantuan bangunan dan berupa bantuan barang. Bantuan berupa barang misalkan: peralatan Laboratorium IPA, Laboratorium Fisika, Laboratorium Komputer dan juga Laboratorium Bahasa, kemudian bentuk buku ke perpustakaan madrasah. Bantuan berupa bangunan yaitu berbentuk uang tunai, dan uang tersebut dugunakan untuk menambahkan ruang kelas baru.Penerimaan bantuan dari pihak pemerintah tidak dilakukan setiap tahun, bentuk bantuan tersebut dilakukan melalui penganalisisan pemerintah terhadap madrasah. dan pihak madrasah mengajukan proposal kepada pemerintah jika pemerintah mengirim bantuan berbentuk uang maka uang tersebut biasanya di transfer melalui Bank dan disalurkan dananya lalu diproses dalam pembanguan atau penambahan ruang kelas yang baru untuk Madrasah Aliyah Swasta ArRosyidiyah Bandung. Bantuan pemerintah yang sering diterima oleh Madrasah 
Aliyah Swasta Ar-Rosyidiyah Bandung yaitu bantuan dari Pemerintah Pusat (APBN), dan Bantuan Pemerintah Daerah (APBD).

Perencanaan sarana dan prasarana Madrasah Aliyah Swasta Bandung memang ditunjang dalam bentuk bantuan dari pemerintah dan bentuk bantuan dari yayasan, bentuk bantuan dari pemerintah sudah dijelaskan di atas. Bentuk bantuan dari yayasan yaitu berupa dana langsung milik yayasan sendiri berupa barang, dan ada bantuan yang bersumber dari orangtua siswa yaitu berbentuk uang tunai dan sejenis barang untuk madrasah, bantuan dari orang tua siswa tersebut bersifat infak bagi madrasah. Hal ini tidak diwajibkan bagi semua orangtua siswa untuk mengirim jenis bantuan apapun atau yang sering terjadi orangtua siswa selalu mengirim uang kepada pihak Madrasah guna mensedekahkan sedikit hartanyauntuk kebutuhan tertentu bagi madrasah, hal tersebut Madrasah Aliyah Swasta Ar-Rosyidiyah Bandung hanya menerima seikhlasnya dari para orangtua siswa, karena memang Madrasah Aliyah Swasta Ar-Rosyidiyah Bandung tidak memberi peraturan untuk menerima infak dan jenis bantuan lainnya setiap bulan atau setiap tahunnya bagi orang tua siswa. Berikut data yang akan dijelaskan mengenai keuangan dan bantuan di Madrasah Aliyah Swasta Ar-Rosyidiyah Bandung.

\section{Pengadaan Sarana dan Prasarana Madrasah}

Proses pengadaan yang dilaksanakan di Madrasah Aliyah Swasta ArRosyidiyah Bandung yaitu melalui beberapa tahap, tahap pertama adalah melakukan seleksi terlebih dahulu, ada seleksi jangka panjang, jangka menengah dan ada seleksi jangka pendek. Bentuk seleksi pegadaan pada jangka panjang yaitu bersifat bangunan karena ada beberapa permasalahan dalam seleksi jangka panjang yang bersifat bangunan yaitu biaya atau dana maka pengadaan terhadap bangunan tersebut dilakukan secara bertahap misalkan dalam jangka waktu dua tahun perencanaan pengadaan di Madrasah Aliyah Swasta Ar-Rosyidiyah Bandung menambahkan satu lokal bangunan saja tergantung dari sumber bantuan pihak pemerintah. Bentuk seleksi jangka menengah yaitu perencanaan pengadaan dalam bentuk ATK (Alat Tulis) dan buku pelajaran bagi siswa setiap pertengahan semester. Sedangkan seleksi jangka pendek yaitu tergantung apa yang dibutuhkan oleh madrasah misalkan perbaikan toilet siswa dan sebagainya. Jika sumber bantuan dari pihak pemerintah tidak mencukupi dalam pengadaan sarana dan prasarana Madrasah Aliyah Swasta Ar-Rosyidiyah Bandung maka dari pihak yayasan sendiri menambahkan dana tersebut untuk melancarkan pengadaan sarana dan prasarana madrasah.

Proses pengadaan sarana dan prasarana di Madrasah Aliyah Swasta ArRosyidiyah Bandung berdasarkan pengajuan proposal, proses tersebut membutuhkan persetujuan dari Kementerian Kabupaten Kota dan direkomendasikan oleh Kanwil Kementerian Provinsi sampai ke Kementerian pusat. Proses pengadaan tersebut setelah melalui tahap persetujuan Kementerian Kabupaten Kota dan Direkomendasikan oleh Kanwil Kementerian Provinsi sampai kepada Kementerian Pusat selanjutnya melalui tahap seleksi di Kementerian Pusat dilihat dari layak atau tidak layaknya jenis pengadaan tersebut. Madrasah Aliyah Swasta Ar-Rosyidiyah setiap tahunnya mengajukan proposal dalam bentuk apapun baik yang berbentuk bangunan maupun berbentuk barang sesuai dari kebutuhan Madrasah. Jenis pengadaan yang 
disalurkan dari pihak pemerintah terus menerus bertahap jika Madrasah Aliyah Swasta Ar-Rosyidiyah mengajukan perencanaan pengadaan jenis bangunan maka tahun selanjutnya Madrasah Aliyah Swasta Ar-Rosyidiyah tidak mendapati saluran dana berbentuk bangunan kembali, bisa saja mengajukan yang lain contohnya mebeulernya atau jenis buku pelajaran dan peralatan lainnya yang dibutuhkan oleh pihak Madrasah hal tersebut sama dengannya dilakukan terlebih dahulu dalam bentuk pengajuan dan tahap seleksi dilihat dari layak dan ketidak layakannya dapat bantuan daru pihak pemerintah tersebut.

Setelah menerima bantuan dari pihak pemerintah berbentuk jenis apapun yang berdasarkan kebutuhan Madrasah maka jenis bantuan tersebut digunakan oleh Madrasah Aliyah Swasta Ar-Rosyidiyah Bandung sesuai dengan Juplak Juknis yang berlaku. Juplak Juknis tersebut dilakukan dengan cara Bimbingan Teknis terlebih dahulu yaitu bimbingan terhadap bagaimana caranya menggunakan dana dan bagaimana cara melaporkannya termasuk durasi waktu proses pengerjaannya, yang dimaksud dari Juplak dan Juknis ini adalah Petunjuk Pelaksanaan dan Petunjuk Teknis. Setelah selesai menerima bantuan dari manapun dari pihak pemerintah dan dari pihak yayasan maka Madrasah Aliyah Swasta Ar-Rosyidiyah Bandung membuat laporan selain berbentuk fisik yang sudah di kerjakan itu dilaporkan maupun yang berbentuk dokumen Photo dan laporan keuangannya pun dilaporkan hal tersebut dilakukan secara tertib agar ada bentuk fisik setelah menerima bantuan dan merencanakan pengadaan sarana dan prasarana di Madrasah Aliyah Swasta Ar-Rosyidiyah Bandung.

Dilihat dari jenis bantuan prasarana yang diterima oleh Madrasah Aliyah Swasta Ar-Rosyidiyah Bandung ada pula jenis barang-barang yang mendukung kegiatan siswa misalnya ATK, dan ada pula jenis peralatan yang mendukung pembelajaran siswa misalnya peralatan Laboratorium IPA, laboratorium Fisika. Itu semua didapatkan melalui bantuan Dana BOS, yang didapatkan bantuan melalui Dana BOS hanya diterima $20 \%$ dari jumlah bantuan setelah dikurangi 50\% untuk Honor. Contohnya: Madrasah Aliyah Swasta Ar-Rosyidiyah Bandung menerima bantuan dari pihak Dana BOS 100.000.000 50\% diambil untuk honor guru berlaku bagi Swasta saja, dan sisa dari $50 \%$ itu diambil $20 \%$ nya untuk pembelian buku.

\section{Pemakaian dan Pemeliharaan Sarana dan Prasarana Madrasah}

Proses pemakaian sarana dan prasarana di Madrasah Aliyah Swasta ArRosyidiyah Bandung berupa bangunan seperti Laboratorium IPA, Laboratorium Fisika, Laboratorium Kimia, Laboratorium Bahasa, dan Laboratorium Komputer itu dilakukan secara bergilir bagi para siswa. Ada jadwal pemakaian tersendiri bagi pemakaian saranaMadrasah Aliyah Swasta Ar-Rosyidiyah Bandung untuk siswa setiap kelasnya.Pemakaian sarana dan prasarana di Madrasah Aliyah Swasta Ar-Rosyidiyah Bandung sesuai dengan jadwal pembelajaran siswa tersebut.

Setiap pemakaian sarana dan prasarana diwajibkan bagi siswa Madrasah Aliyah Swasta Ar-Rosyidiyah Bandung sesuai dengan kebutuhan siswa.Para guru memperbolehkan siswa untuk memakai sarana dan prasarana yang sudah tersedia jika sudah diperizinkan oleh guru kepada siswa tersebut guna mencegah adanya kehilangan maupun kerusakan khususnya bagi prasarana atau peralatan yang mendukung pembelajaran siswa seperti peralatan di 
Laboratorium IPA Laboratorium Fisika, Laboratorium Kimia, Laboratorium Bahasa, dan Laboratorium Komputer. Penggunaan alat ekstrakurikuler seperti bola voli, bola basket, bola sepak sekaligus lapangan olahragapun harus sesuai dengan penggunaan jadwal siswa setiap kelasnya.

Penggunaan bangunan di Madrasah Aliyah Swasta Ar-Rosyidiyah Bandung setiap harinya ada penjadwalan dalam pemakaiannya, dikarenakan Madrasah Aliyah Swasta Ar-Rosyidiyah Bandung terdiri dari Madrasah Diniyah (MD), Madrasah Tsanawiyah (MTs), dan Madrasah Aliyah (MA). Untuk pemakaian gedung tersebut yakni Madrasah Ibtidaiyah (MI), dan Madrasah Tsanawiyah (MTs) masuk pada jam 07:00 sampai dengan 12:00 pagi, tetapi ada perbedaan jadwal pulang bagi siswa Madrasah Ibtidaiyah (MI) hanya beberapa menit saja terhitung dari setelah dzuhur, di lanjut dengan pemakaian gedung bagi siswa Madrasah Aliyah (MA) dimulai dari jam 13:00 sampai dengan selesai pembelajaran.

Proses pemeliharaan terhadap sarana dan prasarana di Madrasah Aliyah Swasta Ar-Rosyidiyah Bandung yaitu melakukan pengecekan setiap Enam bulan sekali di laksanakan oleh Kepala Bidang Sarana dan Prasarana. proses pemeliharaan di Madrasah Aliyah Swasta Ar-Risyidiyah Bandung tidak terpaku dengan pengecekan yang dilakukan pada Enam bulan sekali, proses pemeliharaan dilakukan jika kondisi sarana dan prasarana di perbaiki dan diganti dengan yang baru apabila ada kerusakan didalamnya.

\section{Penginventarisasian atau pengecekan sarana dan prasarana Madrasah}

Proses inventaris atau pengecekan oleh Bidang Sarana di Madrasah Aliyah Swasta Ar-Rosyidiyah Bandung dilaksanakan pada jangka waktu enam bulan sekali sesuai dengan per-setengah semester. Proses pengecekan mengelilingi Madrasah terhitung dari jumlah yang sudah ada, berapa barang yang rusak, dan berapa barang yang masih layak di pakai atau barang yang sudah tidak layak untuk dipakai, barang yang masih bisa diperbaiki dan barang yang sudah tidak bisa diperbaiki secara moril. Contoh: keadaan kursi dan meja di ruangan kelas sedikit goyang karena pengaruh dari kaki kursi dan meja yang rusak, hal tersebut termasuk dari kerusakan yang ringan sehingga perbaikan terhadap kursi dan meja tersebut adalah kaki-kaki kursi dan mejanya saja tidak perlu diganti dengan yang baru. Berbeda dengan kerusakan yang berat contohnya: keadaan kursi dan meja di ruangan kelas sudah lapuk dan benar-benar tidak bisa di pakai hal tersebut mau tidak mau harus diganti dengan yang baru sehingga siswa dapat dengan nyaman dalam proses belajar mengajar di kelas.

Setelah melakukan pengecekan teradap barang maka Bapak Eman Sulaeman melakukan pendataan atau inventarisasi guna memudahkan melihat kondisi sarana dan prasarana di Madrasah Aliyah Swasta Ar-Rosyidiyah Bandung.Proses penginventarisasian terkadang dilakukan dalam waktu sebulan sekali tergantung dari terlihat kerusakan terhadap sarana dan prasarana madrasah, dalam waktu sebulan tersebut Kepala Bidang Sarana dan Prasarana. sendiri bertanggung jawab soal penginventarisasian dimulai dari pendataan barang yang rusak contoh: dari jumlah 20 bangku/kursi yang ada di ruangan kelas sebagian atau tiga kursi yang rusak maka oleh beliau di data dalam penginventarisasian, kelas satu memiliki dua meja dan dua kursi yang rusak maka perlu di data. Proses penginventarisasian dilakukan mencatat 
segala kerusakan sarana dan prasarana di Madrasah Aliyah Swasta ArRosyidiyah Bandung.

\section{Penghapusan sarana dan prasarana Madrasah}

Madrasah Aliyah Swasta Ar-Rosyidiyah Bandung tidak ada peraturan untuk penghapusan sarana dan prasarana apabila rusak, barang yang rusak semacam meja dan kursi Madrasah Aliyah Swasta Ar-Rosyidiyah Bandung menyimpannya di gudang yang berada di belakang sekolah. Apabila ada barang yang rusak berat seperti kursi maka diganti dengan kursi yang berkondisi rusak ringan namun sudah diperbaiki ke ruangan kelas, hal tersebut mencegah pemborosan pengeluaran dana Madrasah. Penghapusan pada barang di Madrasah Aliyah Swasta Ar-Rosyidiyah Bandung dilakukan ketika barang berkondisikan rusak berat, tidak layak untuk dipakai. Proses penghapusan sarana dan prasarana di Madrasah Aliyah Swasta Ar-Rosyidiyah Bandung dipertangggung jawabi oleh pihak kepala madrasah dan kepala bidang sarana dan prasarana yaitu dengan bapak Drs. H. Agus Rahmat, M.M.Pd selaku kepala madrasah dan bapak Eman Sulaeman, S.Pd. selaku kepala bidang sarana dan prasarana di madrasah, proses penghapusannya pun dilaksanakan berdasarkan syarat-syarta dan ketentuan penghapusan sarana dan prasarana yang berlaku yaitu kondisi sarana dan prasarana dalam keadaan sudah tua atau rusak berat sehingga tidak dapat diperbaiki atau dipergunakan lagi, perbaikan sarana dan prasarana akan menelan biaya yang besar sehingga merupakan pemborosan. Hal ini tidak sesuai dengan syarat dan ketentuan penghapusan sarana dan prasarana yang pertama maka Madarasah Aliyah Swasta Ar-Rosyidiyah Bandung tidak melakukan penghapusanterhadap sarana dan prasarana karena dilihat dari kondisi bangunannya tidak ada yang rusak berat maupun berkondisi bangunan tua, karena tujuan dari penghapusan sarana dan prasarana adalah apabila kondisi sarana dan prasarana tersebut benar-benar sudah tidak layak dipakai.Madrasah Aliyah Swasta Ar-Rosyidiyah Bandung jika adabarang yang sudah rusak namun masih bisa diperbaiki barang tersebut dimasukkan kedalam gudang Madrasah, diproses daur ulang diperbaiki kembali. Karena memang kondisi peralatan yang membantu proses pembelajaran siswa yang berbentuk kursi dan meja pada khususnya tidak dilakukan penghapusan walaupun berkondisi rusak, hal tersebut tidak diperbolehkan oleh pihak Madrasah karena barang yang rusak yang berada di gudangpun rata-rata memiliki kondisi yang rusak ringan sehingga tidak ada proses penghapusan barang tersebut.

\section{Faktor penunjang dan penghambat sarana dan prasarana Madrasah}

Faktor penunjang sarana dan prasarana dalam segi perencanaan dan pengadaan sarana dan prasarana di Madrasah Aliyah Swasta Ar-Rosyidiyah Bandung adalah dalam perencanaan pengadaan sarana dan prasarana Madrasah Aliyah Swasta Ar-Rosyidiyah Bandung sudah sesuai dengan hasil perencanaan yang dilakukan setiap enam bulan sekali. Darihasil proses perencanaan pengadaan tersebut, sarana dan prasarana Madrasah Aliyah Swasta Ar-Rosyidiyah Bandungsudah dapat menunjang kebutuhan fasilitas bagi para siswa.

Faktor penunjang sarana dan prasaranaMadrasah Aliyah Swasta ArRosyidiyah Bandung dilihat dari faktor internalnya adalah fasilitas yang memadai yang berada dilingkungan madrasah dapat mendukung proses 
pembelajaran siswa. Tunjangan yang disediakan oleh pihak madrasah berupa sarana dan prasarana adalah bangunan Madrasah, ruangan Laboratorium, Perpustakaan, Majid/Mushola, Kantin, Wifi, dan Speedy. Faktor penunjang sarana dan prasarana Madrasah Aliyah Swasta Ar-Rosyidiyah Bandung dilihat dari faktor eksternalnya adalah pihak madrasah mendapati tunjangan dari pihak pemerintah berupa bantuan barang maupun dana untuk menunjang fasilitas sarana dan prasarana yang ada di Madrasah Aliyah Swasta Ar-Rosyidiyah Bandung.

Faktor penghambat sarana dan prasarana Madrasah Aliyah Swasta ArRosyidiyah Bandung dilihat dari faktor internal dan eksternalnya yaitu dapat dirasakan oleh Bapak Eman Sulaeman.S.Pd. Beliau sudah memegang bidang Manajemen Sarana dan Prasarana di Madrasah Aliyah Swasta Ar-Rosyidiyah Bandung selama delapan tahun.Faktor internalnya adalah bahwa yang memegang wewenang sepenuhnya dalam pengelolaan sarana dan prasarana jika di swasta yaitu kepala madrasah dan kepala yayasan, Bapak Eman Sulaeman.S.pd sendiri tidak sepenuhnya memegang wewenang tersebut.Hanya saja beliau bertanggung jawab atas bidang sarana dan prasarananya yang ada di Madrasah Aliyah Swasta Ar-Rosyidiyah Bandung saja. Yang dimaksud pemegangan wewenang yaitu contohnya atas pendanaan dalam pengelolaan sarana dan prasarana baik dari segi perencanaan pengadaan sarana dan prasarana dan pemeliharaan sarana dan prasarana yang mebutuhkan dana besar. Hal tersebut berbeda dengan sekolah Negeri, jika di sekolah negeri yang menyatakan ACC atau diterima atas pengelolaan sarana dan prasarana yaitu kepala sekolahnya saja begitupun yang pernah beliau rasakan. Di dalam Swasta bidang sarana dan prasarana hanya bisa mengajukan sepenuhnya atas pengelolaan sarana dan prasarana seperti misalnya dalam segi perencanaan pengadaan sarana dan prasarana dan pemeliharaan sarana dan prasarana yang memerlukan dana besar tetapi yang mempunyai hak sepenuhnya dalam menyetujui pengelolaan tersebut adalah kepala madrasah dan kepala yayasan.

\section{Hasil Manajemen Sarana dan Prasarana Madrasah Aliyah Swasta Ar- Rosyidiyah Bandung.}

Hasil manajemen sarana dan prasarana yang ada di Madrasah Aliyah Swasta Ar-Rosyidiyah Bandung dimulai dari perencanaan pengadaan sarana dan prasarana, pemeliharaan dan pemakaian sarana dan prasarana, penginventarisasian sarana dan prasarana, sampai penghapusan sarana dan prasarana sudah berjalan dengan efektif dan efesien, ada hasil tersendiri dari keenam pengelolaan tersebut.

Hasil dari perencanaan dan pengadaan sarana dan prasarana di Madrasah Aliyah Swasta Ar-Rosyidiyah Bandung adalah terbentuknya kerja sama antara kepala bidang sarana dan prasarana beserta kepala madrasah dan juga kepala yayasan untuk merencanankan tunjangan madrasah agar fasilitas yang memadai dapat membantu proses pembelajaran siswa.

Pengelolaan sarana dan prasarana yang ada di Madrasah Aliyah Swasta Ar-Rosyidiyah Bandung didukung oleh pihak internal maupun pihak eksternal.Pihak internalnya sendiri adalah kepala madrasah dan kepala yayasan mengikut sertakan dalam pengelolaan sarana dan prasarana membantu dalam bentuk merencanakan pengadaan sarana dan prasarana bagi 
Madrasah Aliyah Swasta Ar-Rosyidiyah Bandung. Adapun pihak eksternalnya adalah Madrasah Aliyah Swasta Ar-Rosyidiyah Bandung menerima bantuan dari pihak pemerintah dan masyarakat sekitar atas dana pembangunan sarana dan prasarana madrasah yang berbentuk uang maupun barang.

Hasil dari pengelolaan sarana dan prasarana di Madrasah Aliyah Swasta Ar-Rosyidiyah Bandung dilihat dari peninventarisasian atau pengecekan itu dilakukan selama Enam bulan sekali, begitupun dengan pemeliharaan dan pemakaian sarana dan prasarana yang berjalan dengan baik sesuai dengan jadwal pemakaiannya.Terkecualikan dengan pengelolaan penghapusan sarana dan prasarana yang ada di Madrasah Aliyah Swasta Ar-Rosyidiyah Bandung tidak diperbolehkan melakukan penghapusan karena barang yang sudah rusak mungkin masih bisa dipakai, dan terbukti tujuan penghapusan hanya diperbolehkan bagi sekolah yang mempunyai sarana dan prasarana yang memang sudah sangat rusak berat.Dapat disimpulkan hasil dari pengelolaan sarana dan prasarana di Madrasah Aliyah Swasta Ar-Rosyidiyah Bandung yaituberjalan dengan baik.

Hasil dari manajemen sarana dan prasarana di Madrasah Aliyah Swsata Bandung sumber dari siswa nya sendiri yaitu, siswa Madrasah Aliyah Swasta Ar-Rosyidiyah Bandung memiliki 99\% terhadap kepuasan sarana dan prasarana di Madrasah Aliyah Swasta Ar-Rosyidiyah Bandung. Tingkat kepuasan tersebut berdasarkan pemakaian fasilitas sekolah yang sudah sangat memadai hal tersebut mendukung proses pembelajaran bagi siswa.

\section{KESIMPULAN}

Perencanaan sarana dan prasarana MAS Ar-Rosyidiyah Bandung sudah berjalan sangat baik, terhitung dari segi perencanaan pengadaannya, selalu memprioritaskan fasilitas penunjang bagi madrasah untuk membantu pembelajaran bagi siswa. Untuk itu dengan keaktifan dalam perencanaan pengadaan sarana dan prasarana selalu mengajukan bantuan kepada pihak pemerintah dalam proses pengadaan sarana dan prasarana. Hal tersebut menunjukkan bahwa madrasah mementingkan kenyamanan bagi siswa maupun masyarakat untuk penunjangan fasilitas yang memadai.

Pengelolaan pemakaian dan pemiliharaan sarana dan prasarana di sudah berjalan dengan baik. Dalam pemakaian sarana dan prasarana bagi siswa sesuai dengan jadwal yang ditentukan. Pemeliharaan sarana dan prasarana berjalan dengan efektif dan efesien proses pemeliharaan itu sendiri selain bidang sarana dan prasarana yang ada di melibatkan siswa guna menjaga keasrian fasilitas yang ada. Pemeliharaan sarana dan prasarana madrasah dilakukan dengan cara pengecekan setiap bulannya hal tersebut guna menghindar kerusakan bangunan dan menjaga keasrian saranadan prasarana yang ada.

Proses penginventarisasian berdasarkan melakukan pengecekan terlebih dahulu terhadap sarana dan prasarana madrasah. Proses penginventarisasian ini dilakukan dalam jangka waktu enam bulan sekali dengan begitu penginventarisasian berjalan dengan baik.

Proses penghapusan terhadap sarana dan prasarana Madrasah Aliyah Swasta Ar-Rosyidiyah Bandung tidak dilakukan dengan cara semena-mena karena barang yang sudah tidak dipakai berada di gudang namun tidak adanya 
peraturan untuk dihapus karena barang tersebut dimungkinkan masih dipakai, karena kerusakan terhadap barang tersebut seperti meja dan kursi masih terlihat ringan sehingga masih bisa untuk diperbaiki.

Faktor penunjang manajemen sarana dan prasarana adalah fasilitas memadai karena sudah sesuai dengan kebutuhan siswa dan dapat membantu proses pembelajaran, yaitu ada Laboratorium IPA, Biologi, Bahasa, dan Laboratorium Komputer. Sedangkan faktor penghambat sarana dan prasarana. Faktor internalnya memerlukan atau kekurangan dana bagi madrasah untuk melaksanakan perencanaan pembangunan sarana dan prasarananya. Sedangkan faktor eksternalnya adalah penyaluran bantuan dari pihak pemerintah yang memerlukan beberapa tahap. Hal tersebut menghambat pengelolaan sarana dan prasarana khususnya bagi perencanaan pengadaan sarana dan prasarana.

Hasil manajemen saranadan prasarana mulai dari perencanaan sarana dan prasarana, pengadaan sarana dan prasarana, pemakaian dan pemeliharaan sarana dan prasarana, penginventarisasian sarana dan prasarana sampai penghapusan sarana dan prasarana sudah sangat berjalan dengan baik efektif dan efesien. Fasilitas dinilai dengan baik, hal itu dirasakan oleh siswa, yaitu bahwa sarana/fasilitas yang ada dapat membantu pembelajaran siswa.

\section{REFERENSI}

Darmastuti, H. (2014) Manajemen Sarana dan Prasana dalam upaya peningakatan kualitas pembelajaran Jurnal Inspirasi Manajemen Pendidikan Volume 3, Nomor 3, Januari 2014. Dalam http://jurnalmahasiswa.unesa.ac.id/index.php/inspirasi-manajemenpendidikan/article/view/6606 Di akses pada 30 Desember 2017 pkl 24:00

Fuad, N. (2014). Manajemen Pendidikan Berbasis Masyarakat Konsep dan Strategi Implementasi.

Fuad, N. (2016). Manajemen Sarana dan Prasarana Pendidikan. Jakarta: PT Raja Grafindo Persada.

Gunawan, A. H. (1996). Administrasi Sekolah (Administrasi Pendidikan Mikro, Jakarta, PT Rineka Cipta.

Kurniawati, P.I. (2013). "Manajemen Sarana dan Prasarana di SMKN 1 Kasihan Bantul”. Jurnal Akuntabilitas Manajemen Pendidikan. Vol.1. No.1 hal. 101. Dalamhttps://id.portalgaruda.org/?ref=browse\&mod=viewarticle\&article=28 2671 Diakses pada tanggal: 16 Juli 2018.

Marmo'ah, S. (2014). "Manajemen sarana dan Prasarana Di SMAN Titian Teras Mu'aro Jambi". Jurnal IImiah Univenrsitas Batanghari Jambi. Vol. 14. No.4. https://id.porta;garuda.org/index.php?ref=browse\&mod=viewarticle\&article $=521370$ Diakses pada tanggal: 16 Juli 2018 .

Megasari, R. (2014) "Peningkatan Pengelolaan Sarana dan Prasarana Pendidikan Untuk Meningkatkan Kualitas Pembelajaran di SMPN 5 Bukittinggi". Jurnal Administrasi Pendidikan. Vol. 2 No. 1 Hal. 638. http://ejournal.unp.ac.id/index.php/bahana/article/viewfile/3808/3041

Diakses pada tanggal: 16 Juli 2018. 
Ike Malaya Sinta

Mulyasa, E. (2002). Manajemen Berbasis Sekolah. Bandung, PT Remaja Rosdakarya.

Munir, M. (2014). Manajemen Sarana dan Prasarana dalam upaya meningkatkan mutu pendidikan. Jurnal Inspirasi Manajemen Pendidikan Volume 4 Nomor 4 April 2014. http://jurnalmahasiswa.unesa.ac.id/ index.php/inspirasi-manajemen-pendidikan/article/view Di akses pada 01 Januari 2018 pkl 08:25

Solichin, M.M. (2011). "Manajemen Sarana dan Prasarana Pendidikan di STAIN Pamekasan". Jurnal Nuansa. Vol.8 No. 2. Hal. 155. http://dx.doi.org/10.19105/nuansa.v8i2.10 